\title{
UNA LANZA POR UN PROYECTO DE NACIÓN: NADAÍSMO 70
}

\author{
Álvaro Acevedo Tarazona ${ }^{1}$ \\ Universidad Industrial de Santander - Colombia \\ tarazona20@gmail.com \\ Rina Alexandra Restrepo ${ }^{2}$ \\ Estudiante de Maestría \\ Universidad Tecnológica de Pereira-Colombia \\ rinaalexandra@gmail.com
}

Recepción: 30/05/2008

Evaluación 07/10/2008

Aceptación: 16/06/2009

Artículo de Reflexión

\section{RESUMEN}

La revista Nadaísmo 70 fue el medio de expresión de un movimiento literario y político de vanguardia que dejó una huella perdurable en la cultura intelectual colombiana. Cincuenta años después del origen de este movimiento, es importante preguntarse por su corta publicación seriada (sólo ocho números) y por algunos de los contenidos, temáticas e influencias, en especial por su crítica mordaz a las tradiciones políticas del momento, y por las representaciones más arquetípicas de las que se valieron para expresar sus concepciones estéticas sobre el estado social del momento. Este es un primer balance investigativo en el marco de un proyecto más amplio sobre la cultura política e intelectual de los años sesenta y setenta en Colombia, en particular sobre las influencias e impactos de Mayo del 68 en Colombia y América Latina. Los nadaístas irrumpieron en la cultura política e intelectual de los años cincuenta y sesenta para desafiar los esquemas tradicionales de la sociedad. Con su actitud iconoclasta y crítica plasmaron en sus escritos e imágenes una visión de la realidad social y crearon una impronta ideológica y estética propia. Ellos instauraron una ruptura de lo cotidiano y

\footnotetext{
1 Doctor en Historia, Profesor titular de la Universidad Industrial de Santander. Director del grupo de investigación Políticas, Sociabilidades y Representaciones Histórico-Educativas (PSORHE).

2 Licenciada en Español y Comunicación Audiovisual y estudiante de la maestría en Literatura y Filosofia de la Universidad Tecnológica de Pereira. Integrante del grupo de investigación PSORHE.
} 
Una lanza por un proyecto de nación: nadaismo 70

sintetizaron su propósito en una frase de Frantz Fanon que compartieron: "querer apegarse a la tradición o reactualizar las tradiciones abandonadas, es no sólo ir contra la historia, sino contra su pueblo"3.

Palabras Claves: Nadaísmo, Movimiento Cultural, Literatura, Política, Estado, Nación, Colombia.

\title{
A LANCE FOR A NATION PROOJECT: NADAÍSM 70
}

\author{
Álvaro Acevedo Tarazona \\ Universidad Industrial de Santander - Colombia \\ tarazona20@gmail.com \\ Rina Alexandra Restrepo \\ Estudiante de Maestría \\ Universidad Tecnológica de Pereira - Colombia \\ rinaalexandra@gmail.com
}

\begin{abstract}
The magazine Nadaísmo 70 was the means of expression of a literary and political movement of vanguard that left a lasting track in the Colombian intellectual culture. Fifty years after the origin of this movement, it is important to ask for its short seriada publication (only eight numbers) and by some of the contents, thematic and influences, in special by its mordacious critic to the political traditions of the moment and by the arquetípicas representations of those than they were worth to express its aesthetic conceptions on the social state of the moment. This it is a first investigativo balance within the framework of a ampler project on the political and intellectual culture of the Sixties and seventy in Colombia, in individual on the influences and impacts of May of the 68 in Colombia and Latin America.

The nadaístas burst in into the political and intellectual culture of the Fifties and sixty to defy the traditional schemes of the society. With their attitude iconoclasta and critic shaped in their writings and images a vision of the social reality and created one impronta ideological and aesthetic own. They restored a rupture of the daily thing and synthesized their intention in a phrase of Frantz Fanon that shared:? to want to become attached themselves to the tradition or to reactualizar the left traditions, it is not only to go against history, but against its town?
\end{abstract}

Key Words: Nadaísmo, cultural movement, Literature, policy, State, nation, Colombia.

${ }^{3}$ ARANGO, Gonzalo. (1970): Nadaísmo 70. No. 2, p. 18. 


\section{INTRODUCCIÓN}

En una crónica periodística de El Tiempo del 31 de agosto de 2008, se hizo un homenaje a las bodas de oro de este "movimiento literario, filosófico, artístico y social" que nació en 1958 en pleno tránsito de la dictadura de Rojas hacia el pacto del Frente Nacional. En su momento, el escritor antioqueño Gonzalo Arango reclutó a un grupo de jóvenes para "envenenarlos" con su recién creado Nadaísmo, un movimiento de prédica sobre la creencia en la Nada y emparentado con el Dadaísmo, el Surrealismo, el Nihilismo y sobre todo con el Existencialismo de Sartre y Camus. ${ }^{4}$ Corrían los años sesenta y por supuesto también fueron evidentes las influencias de Mayo del 68, de la revolución cubana, del movimiento por los derechos civiles en Estados Unidos, del pop art, de la nueva ola, entre otras expresiones y consumos de la revolución cultural planetaria experimentada en esta época.

El primer Manifiesto Nadaísta dejó impresas las huellas del itinerario político y cultural de este movimiento: «Destruir un orden es por lo menos tan difícil como crearlo (...) Ante empresa de tan grandes proporciones, renunciamos a destruir el orden establecido. La aspiración fundamental del Nadaísmo es desacreditar ese orden”. En el mismo escrito, expresaron su nueva fe iconoclasta: «En esta sociedad en que la mentira está convertida en orden, no hay sobre quién triunfar sino sobre uno mismo. La misión es no dejar una fe intacta, ni un ídolo en su sitio. Todo lo que esté consagrado como adorable será examinado y revisado." " Lanza en ristre contra las tradiciones literarias colombianas del momento, no dejaron "'títere del sistema con cabeza", a excepción de León de Greiff y Fernando González. También atacaron los cimientos de la Iglesia, el establecimiento, la herencia hispánica y el pacto bipartidista del Frente Nacional. Estaban cansados, dice Jotamario Arbeláez, de rendirle pleitesía a María de Jorge Isaac.

No han sido pocos los críticos o defensores del Nadaísmo. Una de las más fuertes críticas proviene de las veleidades y delicuescencia de Gonzalo Arango, su fundador:

Aliado de la dictadura de Rojas Pinilla, cuando se cayó tuvo que huir a Cali, donde alabó a la juventud que "aportó su sangre y el sentido heroico del sacrificio para derrumbar una tiranía castrense”. En 1968 saludó al presidente Carlos Lleras Restrepo como el 'poeta de la acción', en 1970 apoyó la candidatura presidencial de Belisario Betancourty en sus últimos años se dedicó a escribir textos místicos. ${ }^{6}$

Más allá de juzgar las actuaciones de los exponentes del Nadaísmo, se trata de analizar su producción cultural y literaria a partir de la publicación seriada Nadaísmo 70 y preguntarse por los contenidos que en su momento dialogaron con el contexto social y político del país.

\footnotetext{
4 EL TIEMPO. (2008): "La Furia Nadaísta", en El Tiempo, agosto 31. Extraído el $1^{\circ}$ de septiembre

6 CAMBIO. (2008): "50 años no es nada”, en Cambio. No. 1374, septiembre 1 a 8, pp. 84-85.
} 


\section{Palabra e Imagen: Una Aproximación Metodológica}

Hoy, después de cincuenta años, ante las críticas que señalan a los nadaístas con "bufones que divirtieron a las clases altas de un país que se moría de tedio", especialistas en el tema defienden la obra literaria de algunos de sus miembros: los cuentos y poemas de Amilkar Osorio, la poesía de Jaime Jaramillo Escobar, el trabajo periodístico y literario de Eduardo Escobar, las novelas de Humberto Navarro, la poesía de J. Mario y de Darío Lemos, los cuentos de Barquilo y los dibujos de Malgren Restrepo. ${ }^{7}$ Cincuenta años después de estas "Bodas sin oro", como ellos las llaman, el poeta Jotamario ondea una lanza por el movimiento: "Ni más faltaba que el Nadaísmo fuera a dejarle algún legado o herencia a la Colombia de hoy, su hija calavera, bastarda y desheredada. Cumplimos con avizorarle lo que le iba a pasar". ${ }^{8}$

Lo cierto es que ante las contundentes críticas o defensas a ultranza que se puedan hacer del Nadaísmo, poco se ha estudiado la incidencia de este movimiento en la producción escrita, y más específicamente en los ocho números de su producción seriada Nadaísmo 70. Una primera aproximación investigativa a las temáticas de esta revista es reveladora sobre los contenidos políticos, sociales y culturales que en este medio se expresaron. En 1970 Gonzalo Arango editó la primera revista que se publicó irregularmente durante 1970 y 1971. Fueron ocho números publicados de manera intermitente que contaron con la participación de Mario Rivero, Jaime Jaramillo Escobar (X-504), Eduardo Escobar, Elmo Valencia, Amílcar Osorio, Ernesto Cardenal, Carlos Eduardo Jaramillo, Humberto Navarro y Fernando González. Algunos de estos escritores recibieron excomunión y cárcel por publicar en la revista Nadaísmo 70 posiciones radicales contra la religión, el Estado y la academia. Esta rebeldía expresada en la revista Nadaísmo 70 también permite identificar en sus páginas una sintonía con la revolución cultural planetaria.

\section{Las Representaciones en Nadaísmo 70}

El mundo antropológico es reconocido por la construcción simbólica e imaginativa de la cultura, y en un tránsito continuo de la pulsión a lo natural, de lo cultural al contexto. ${ }^{9}$ En la revaloración del papel gnoseológico y ontológico de la imaginación y del símbolo como creador de sentido y de cultura, el ser humano se aleja de la naturaleza y crea el mundo social. Mientras el mundo ontológico reduce y recorta la percepción de los individuos, el mundo de las representaciones, construido por la imaginación, desempeña un papel preponderante como fuente creadora de sentido, de cultura y de arte. Gracias a la imaginación es posible superar las distancias, involucrar valoraciones que permiten idear nuevas realidades y fortalecer la memoria cultural y las representaciones colectivas. El símbolo del Che Guevara, por señalar la poderosa construcción imaginativa de la cultura, se constituyó en ícono para las generaciones de

7 Ibídem, p. 85.

8 Ibídem, p. 70

9 DURAND, Gilbert. (2004): Las estructuras antropológicas del imaginario. México.

Fondo de Cultura Económica. 
los años sesenta y setenta y en un tema central de la revista Nadaísmo 70: "Hay que cambiar ante todo la mentalidad de las masas para lograr un hombre nuevo". ${ }^{10}$

La actitud irreverente de los nadaístas y su defensa del arte como expresión cultural fue una constante de inspiración que los llevó a construir, en su publicación seriada, símbolos, caricaturas irreverentes e imágenes a partir de elementos como la antítesis, el geometrismo, la desagregación de los estados emocionales del ser humano y el solipsismo, características que moldearon los movimientos culturales de la época y la construcción de ciertas representaciones intelectuales en la nación colombiana (Véase gráfica 1: Arte abstracto, Nadaísmo 70, No. 8, p. 13).

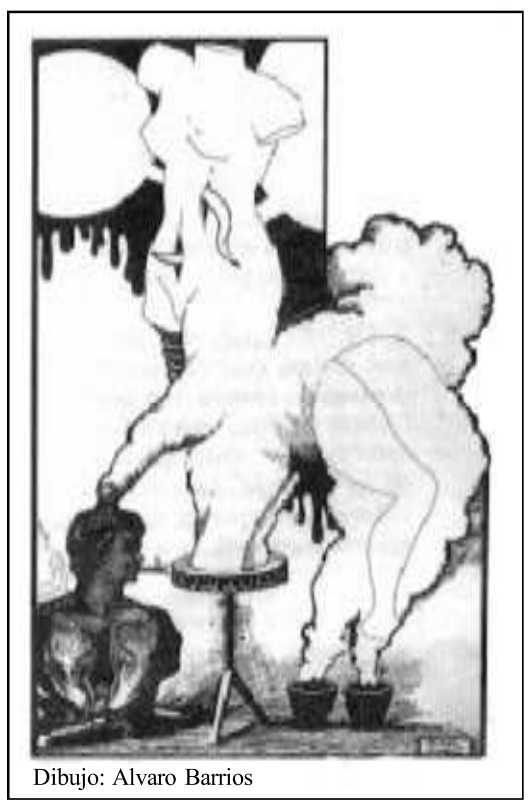

Gráfica 1

Los nadaístas hicieron uso de la imaginación y la crítica mordaz para expresar en su revista nuevos elementos de representación de la realidad colombiana. Con caricaturas como "La rebelión en América" desafiaron abiertamente la autoridad oficial del Estado, criticaron la invasión norteamericana en "El pis de la Coca-cola" y diseñaron un "New map of America del Sur" (Véase gráfica 2, Mapa de América Nadaísmo 70, No. 8, p. 8). Las historietas de Snoppy, que representaron la posición radical del movimiento nadaísta, criticaron los idealismos católicos y convencionales (Véase gráfica 3, Snoopy, Nadaísmo 70, No. 4, p. 7).

También se valieron de imágenes publicitarias como Fumigax para recordarle al público lector que este veneno era efectivo para acabar con "la plaga del nadaísmo". La

lectura que hicieron los nadaístas de lo político exploró el proyecto de nación inacabado en el que se debatía el país entre dos fuerzas: lo tradicional y lo moderno. Este pensamiento quedó sintetizado en la ideología del movimiento hippie que abogó por una noción de reconocimiento y forma de vida particular: "Hermanos: el espíritu del Nuevo Mesías puede no venir a nosotros sino de nosotros"11.

10 ARANGO, Gonzalo. (1970): "Diccionario Revolucionario", en Nadaísmo 70. No. 7, p. 33.

11 ARANGO, Gonzalo. (1970): "Estados Unidos, Los Hiipies", en Nadaísmo 70. No. 5, p. 55. 


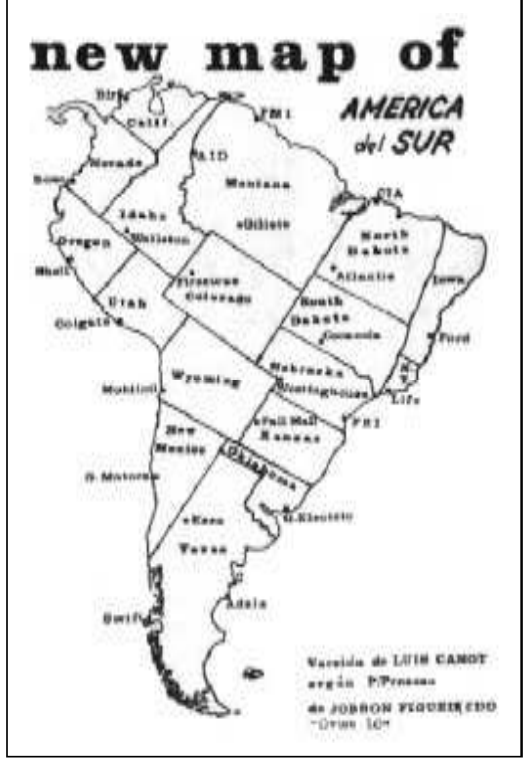

Gráfica 2

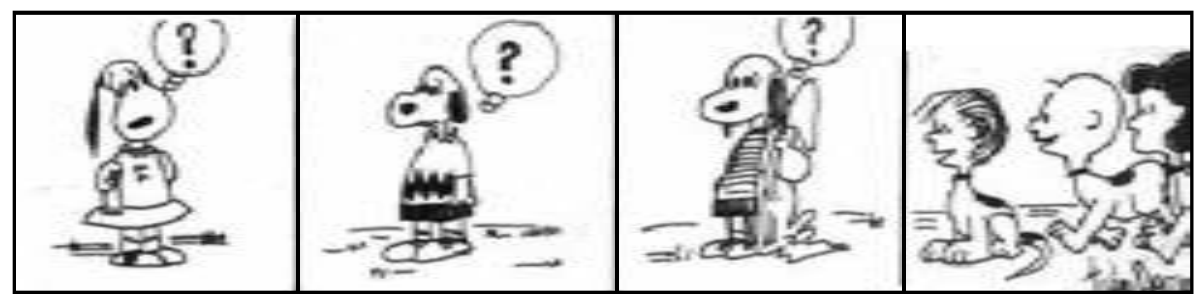

Gráfica 3

\section{Ascensos y descensos: claroscuros en los regímenes de luz y oscuridad}

Gilbert Durand plantea que hay dos regímenes de la imagen: uno diurno y otro nocturno. En toda cultura se privilegia uno de ellos, pero siempre hay una polaridad, un juego permanente entre los dos, una dialéctica entre lo apolíneo y lo dionisíaco. La civilización oriental y occidental están influidas por estos dos regímenes de la imagen: la primera está más próxima del régimen de la nocturnidad y la segunda del diurno. La crítica al sistema político colombiano y las contradicciones permanentes del movimiento nadaísta con el Estado los hizo incurrir en un ascenso y descenso permanente por dos regímenes de la imagen: el diurno y el nocturno. La exploración de los símbolos culturales, las obras de arte y la literatura permite estudiar el recorrido humano por los regímenes de la imagen. En el ser humano conviven los dos regímenes, se equilibran, 
existe la prevalencia de ciertas imágenes y elementos: el aire y el fuego serían más del régimen diurno; la tierra y el agua, del régimen nocturno.

El régimen diurno se caracteriza por las imágenes geométricas y esquizomorfas que son propias de la cultura occidental, es el régimen diairético, de la separación y la antítesis, pero en ningún momento es un régimen esquizomorfo de patología; son las formas y representaciones las que conducen hacia allá. La concepción de patología en Gilbert Durand, en Ernest Cassirer o en Carl Gustav Jung es una ausencia de imaginación y de incapacidad para simbolizar. Las expresiones esquizomorfas en el régimen diurno se pueden ver en ciertas obras de arte como el "Guernica" de Picasso, donde las imágenes en blanco y negro están un poco separadas y fragmentadas.

En movimientos artísticos como el Cubismo, las imágenes tienen que ver con el geometrismo; también ciertas realizaciones impresionistas poseen esta misma característica. Cézanne planteaba que todas las cosas de la naturaleza se podían compendiar en formas geométricas. Algunas imágenes de la revista Nadaísmo 70 presentan estas características, como la ilustración de la revista Nadaísmo No. 3 al poema "Auténtico Ser" de Andrés Holguín (Gráfica 4), o el "Panorama de la situación actual del arte colombiano" en la revista Nadaísmo No. 4 donde se presenta una imagen abstracta y fragmentada (Gráfica 5).

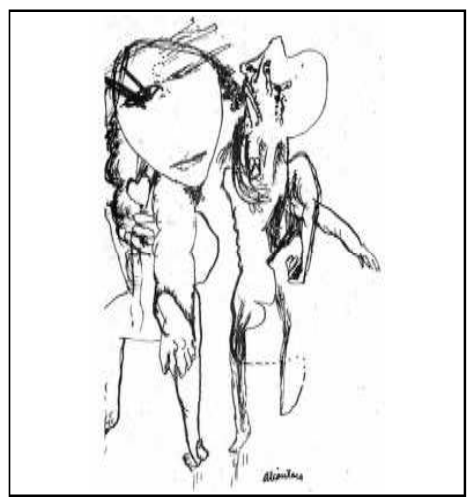

Gráfica 4

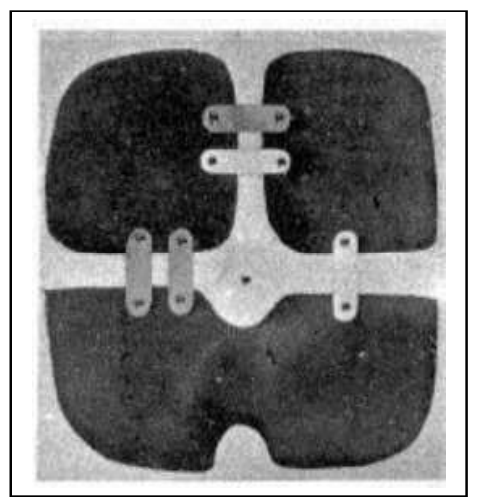

Gráfica 5

El régimen nocturno de la imagen se caracteriza por imágenes melancólicas que son recurrentes en la cultura oriental y en el romanticismo. En la revista Nadaísmo 70 estaba representado por la idea del descenso, por la búsqueda de otros mundos, del inconsciente, del simbolismo y la exaltación de la noche. Este régimen se exalta en el gran arquetipo de las diosas madres. Los nadaístas proponían dicha exaltación sobre la vanguardia del hombre rebelde, que entraba en una ruptura consigo mismo y con la sociedad. Un ser inmerso en las oscuras noches del alma (Véase gráfica 6, Snoopy, Nadaísmo 70, No. 4, p. 7). 


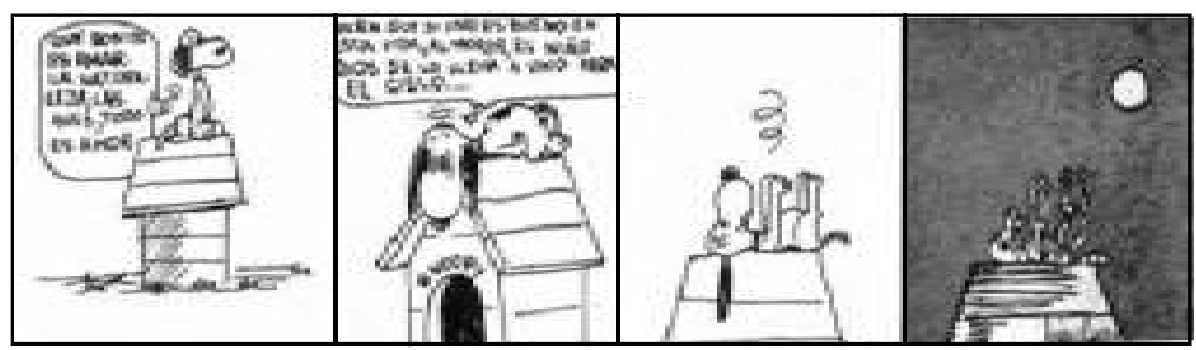

Gráfica 6

La crítica al pensamiento racional es característica del régimen diurno de la imagen. Los nadaístas entraron en contacto con ese hombre primitivo que aún está cerca de nosotros. Aunque exista un gran avance tecnológico y de la ciencia, el problema radica en exacerbar este avance hasta llegar a un logocentrismo que desencadena en una verdadera patología y una negación del estadio animista de la humanidad. Esto fue lo que hizo el positivismo de Comte al partir del presupuesto de que el hombre ya había superado sus estadios primitivos, aquel estadio animista del ser humano, que para Gilbert Durand es el momento del símbolo, el momento mítico de la creación poética y el momento en el que surge la cultura.

La cultura occidental se caracteriza por el predominio de lo racional y del pensamiento científico, limita lo instintivo, por eso las imágenes se han ido al inconsciente, donde el ser humano debe hacer un balance entre el mundo consciente $\mathrm{e}$ inconsciente, que lo lleva a acercarse a sus impulsos, al mito y al símbolo. La aspiración de los nadaístas radicaba precisamente en escapar de ese sistema capitalista e imperialista que llevaba a la automatización, la enajenación y la futilidad de la sociedad.

El régimen diurno de la imagen se construye por antítesis y dialéctica. Este régimen, que surge como antítesis, hace una negación de lo femenino. Las imágenes femeninas se representan como tereomorfas o de descenso, catamorfas o de la noche y lictomorfas. Estas representaciones se encuentran en algunos poemas de la revista Nadaísmo 70 como la "Oración Nadaísta a la Malísima Brigitte Bardot" de Amílcar Osorio, los "Poemas de la Ofensa" de X-504, la "Balada y salmo para Escoltar a Mary Jo" o la "Definición de Sharon Tate" en los poemas de Javier Iván Barrios (Véase gráfica 7, Régimen diurno, Nadaísmo 70, No. 2, p. 18). 


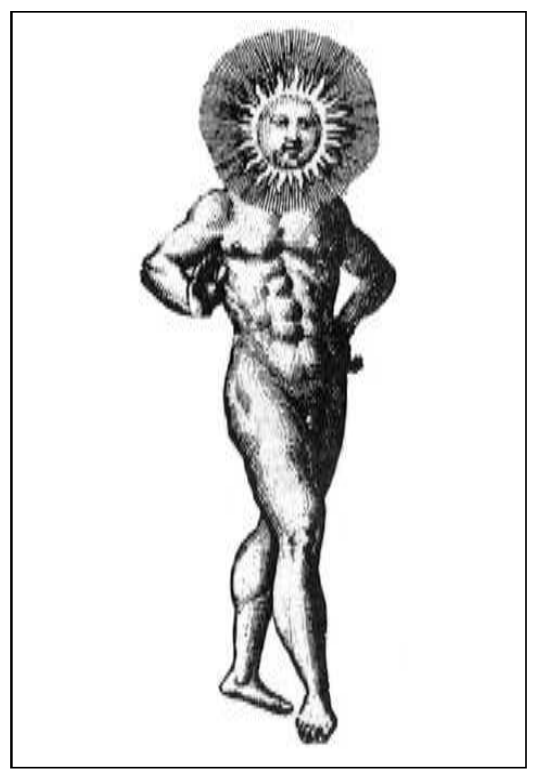

Gráfica 7

\section{Romper las Raíces}

La revista Nadaísmo 70 constituyó un ejercicio intelectual de un movimiento que estuvo siempre en contra de la tradición. Sus representaciones construyeron imágenes mordaces del país. El llamado era al cambio. En uno de los números de la revita Nadaísmo 70, Germán Castillo Bernal hizo una reflexión sobre la tarea histórica de la universidad colombiana para promover el cambio. La universidad como conciencia crítica y expresión de la sociedad debía "propiciar la creación de un hombre nuevo, que sea capaz de entregarse desinteresadamente; pero no habrá hombres nuevos mientras esté en vigencia la vieja moral, la que han defendido -con sus ideas y con la sangre de las clases de abajo-los partidos y las clases de arriba"12.

El nadaísmo atacó la doble moral de la sociedad, de la Iglesia, de la academia, de la literatura, de la universidad, del gobierno y de las instituciones. Sin fomentar una actitud propia de rebelión contra el orden establecido, los integrantes más bien buscaron hacer evidente una estructura agonizante y disfuncional del Estado. Siendo hoy el movimiento cultural más controvertido de la literatura colombiana, la etimología a la que recurrió, la Nada, era la búsqueda de una estética destructora y creadora que no tenía como fin cambiar la sociedad sino incidir en la acción del cambio mediante la provocación a las clases sociales en el poder y a toda forma de tradición.

En la identificación de loa nadaístas con el régimen diurno de la imagen (régimen de la antítesis, de la contradicción), se reforzaba la idea de ir en favor de un estado de locura y suicidio: "El nadaísmo es un beso enviado desde la punta de un guante de box"13. El geometrismo y las estructuras esquizomorfas son perfectamente identificables en los poemas del movimiento nadaísta en su propósito de crear una experiencia particular. Las pulsiones y fuerzas que movieron a los poetas nadaístas eran también una forma de desvelar la cultura patriarcal colombiana y sus símbolos emblemáticos: la espada, la figura del héroe, de Ícaro y de Matusalén. Imágenes que fueron recurrentes en sus temáticas de luz y oscuridad (Véase gráfica 8, Espada, Nadaísmo 70, No. 6, p. 53).

\footnotetext{
12 CASTILLO BERNAL, Germán. (1970): "Bolsa de Valores, el cambio social a través de la Universidad", en Nadaísmo 70. No. 4, p. 37.

13 ARANGO, Gonzalo. (1970): "Definiciones", en Nadaísmo 70. No. 1, p. 3.
} 


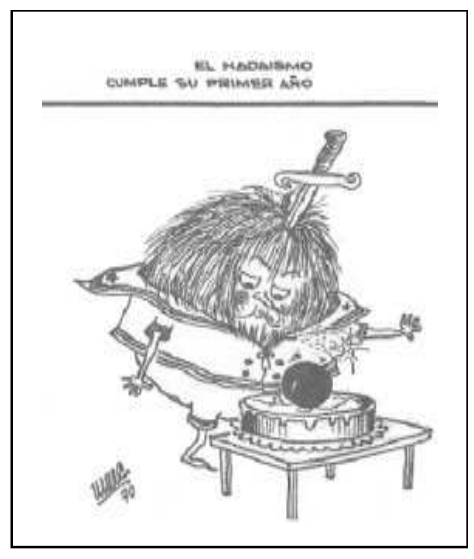

Gráfica 8
Las creaciones poéticas de los nadaístas tenían doble polaridad. Por un lado, el aspecto ascensional, que se dirigía hacia el cielo; por el otro, el descenso o la caída a las cavernas, representado en diferentes símbolos que poseían una naturaleza teórica o esquizomorfa, caracterizada por la división, la fragmentación y el análisis. La teoría analítica y la estructuralista pertenecen al régimen diurno de la imagen, expresión de una lógica analítica y matemática, un geometrismo y una manera de percibir el mundo. En los nadaístas esta representación se identificaba con la "sociedad burguesa" colombiana y con sus esquemas sociales y sus instituciones rígidas.

El régimen diurno con sus imágenes de ascensión estuvieron representadas en la figura emblemática del Che Guevara, símbolo del héroe, de la lucha y del cambio que trascendió su propia muerte y se constituyó en ejemplo a seguir por los jóvenes revolucionarios. La figura bíblica de Matusalén representó el Estado longevo y despótico que inauguró la dictadura de Rojas Pinilla. En la revista Nadaísmo 70, Rojas Pinilla quedó descrito como un monstruo infernal que debía ser aniquilado por el héroe. La luz y las tinieblas en que se debatió el estado colombiano durante los años sesenta y setenta representaron para los nadaístas un Leimotiv, y en varios de sus poemas y manifiestos se aprecia una interesante transición entre el régimen de la luz y la oscuridad. Este proceso interesante en la narrativa del movimiento se observa en los siguientes párrafos: "Antes del NADAísmo yo era una torre que había sido invadida por los duendes, nada ardía en el cielo que era como un cienoso techo, la luz había hundido sus patas en la oscuridad del mediodía. Y yo pasaba debajo de soles sin notarlos, y tenía manos y no tocaba, y tenía oídos y no oía."14

La rebeldía en este movimiento representó también el proceso diairético y de separación de la tradición y la "normalidad" social siempre en contra del sistema y en contradicción permanente. El estado autístico es un retroceso, una separación de la realidad que va operando en el individuo, eso es lo que se ve en determinadas obras cuando un autor desentraña sus monólogos interiores. En la obra de Kafka hay un cierto retroceso autístico, un alejamiento del mundo y de la realidad. En la creación poética de los nadaístas se evidencia un alejamiento de la sociedad y un corte con el mundo, característico de la conciencia escindida que expresaron. Ellos fueron solitarios, el mundo no les interesaba. La nada era su consigna y una forma de expresar sus búsquedas individuales y colectivas.

\footnotetext{
14 ESCOBAR, Eduardo (1970): “A Regis Debray”, en Nadaísmo 70. No. 2, p. 14.
} 
El periodo de tinieblas que vivió el pueblo colombiano por la violencia generalizada también condujo a los poetas nadaístas a emerger de la oscuridad, que ellos definieron como un faro de luz que se contraponía a las sombras tenebrosas que padecía la nación. $\mathrm{Al}$ igual que Ícaro, realizaron un descenso a las profundidades de los abismos. En sus versos transgredieron las normas de la época y sufrieron como Ícaro, con sus alas partidas, una profunda caída a los abismos de las tinieblas y la incomprensión: "El sol huyó de su paso, mensajero de fatalidad. Decapitó el águila del escudo soberano y en su lugar instaló un cuervo horrendo, tenebroso, símbolo del poder que alimentaba sus abismales delirios"15. En este fragmento -el proceso de desagregación, expresión régimen diurno de la imagen (un ser escindido entre la "normalidad" y la paranoia)-, se inauguró otra característica del régimen diurno en el que la fragmentación, el mimetismo y el pensamiento por antítesis prevalecieron en las representaciones. Así, el sol desaparece y pasa a formar parte de una imagen nocturna, vigilante y silenciosa, representada en el cuervo que tanto obsesionó a los nadaístas y que estuvo presente en las escasas ocho publicaciones de la revista. El cuervo era símbolo nefasto que presagiaba desgracias. En contraposición, El búho, testigo atento y vigilante del sino trágico de la sociedad colombiana.

Gonzalo Arango en su escrito "Entre la espada y la oligarquía" expuso las vivencias de un ser marginado de la humanidad que vivía en un sin sentido, en una profunda melancolía. De esta manera, intentaba mostrar una característica fundamental del régimen nocturno de la imagen:

Existen formas de opresión modernas legalizadas, infinitamente crueles, como morder cada día un pan de miseria, no tener trabajo, educación, salud, esperanzas. Ser un marginado de la humanidad, un bastardo social. He aquí la peor ignominia que puede sufrir un ser humano: vivir para nada, ser nadie. ${ }^{16}$

En este fragmento se aprecia una negación de la negación del tiempo, de las instituciones sociales y de la misma vida. Los nadaístas arrastraron todo a su paso. Las imágenes de su creación estética traen hasta hoy importantes figuras arquetípicas del rechazo a toda forma de autoritarismo, de tradiciones parasitarias y de formas institucionales corruptas (Véase gráfica 9, Imágenes fragmentadas, Nadaísmo 70, No. 5, p. 13).

15 ARANGO, Gonzalo (1970): “Última Página, Los Genocidas", en Nadaísmo 70. No. 2, p. 41.

16 ARANGO, Gonzalo. (1970): "Entre la Espada y la Oligarquía”, en Nadaísmo 70. No.

2, p. 3. 


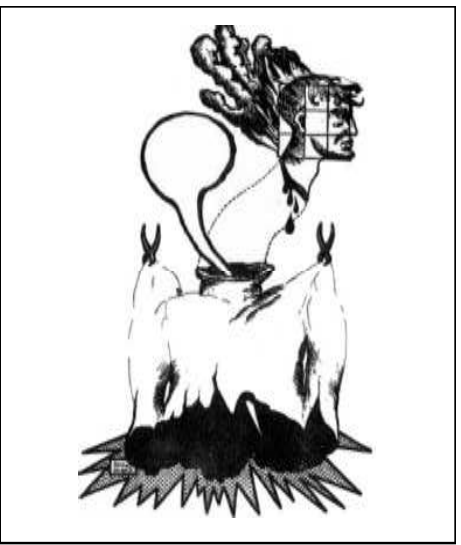

Gráfica 9
El Estado colombiano fue representado por los antiguos monstruos ctónicos que salían del Hades para traer muerte y destrucción. Los nadaístas atacaron a la religión cristiana porque consideraban que en una época de profundos cambios culturales la figura mítica de Jesús, como cordero y redentor del mundo, había perdido su vigencia. El movimiento mostró cómo la angustiante muerte que trajo consigo la salvación o la condena eterna fue perdiendo su influjo ideológico en el pueblo. De alguna manera la muerte fue exorcizada y perdió "las connotaciones aterradoras con que estaba impregnada en el régimen diurno, siendo vista ahora como un "retorno al hogar", como el fin de la separación

de las entrañas de la Madre-Tierra". ${ }^{17}$ La lucha entre el mito y el logos eran dos fuerzas en tensión en las representaciones de los nadaístas, una oposición entre el pensamiento religioso y el pensamiento racional. En la edición No. 3 de Nadaísmo 70, Gonzalo Arango expuso en el "Sermón contra Jesús" esta lucha de contrarios: "Vivimos en los subterráneos de la mente, ser-vil-mente, a la sombra del Hombre, ocultándonos de él. El fantasma de Cristo empavorece las almas, eclipsa la Tierra. Aún no hemos asomado la cara al verdadero Sol." 18

La religión fue cuestionada y atacada por los nadaistas. El cielo del cristianismo es bajado del paraíso a la tierra, cobrando un nuevo auge las imágenes religiosas de Oriente que inauguraron el misticismo Zen. Esta connotación permite aún identificar la polarización de un régimen patriarcal cristiano que se fundamenta en el régimen diurno de la imagen a uno nocturno que privilegia las imágenes místicas y el retorno hacia el mismo hombre. La manera como el movimiento nadaísta percibió la sociedad quedó plasmada en los textos impresos de la revista Nadaísmo 70. En esta publicación se mostró un país que se debatió a lo largo de su historia en una caótica confrontación bipartidista (liberales y conservadores). La violencia reaparecía a través de un tiempo cíclico y un eterno retorno: "La violencia que, más allá de su materialidad, comanda así a un imaginario en el que adquiere la figura de un destino que estaría condenado a repetirse sin fin." ${ }^{19}$ En los versos de rebeldía del movimiento nadaísta se actualizaron imágenes poderosas como la justicia, representada en la espada, y el búho, representada en el centinela de la noche profunda (Véase gráfica 10, El búho, Nadaísmo 70, No. 3,

\footnotetext{
17 GARAGALZA, Luis. (1990): La interpretación de los símbolos. Barcelona. Anthropos, p. 80.

18 ARANGO, Gonzalo. (1970): "Sermón contra Jesús", en Nadaísmo 70. No. 3, p. 11.

19 PÉCAULT, Daniel. "Violencia, guerra y paz: Reflexiones sobre la violencia en Colombia". Cali. Universidad del Valle, pp. 26-27.
} 


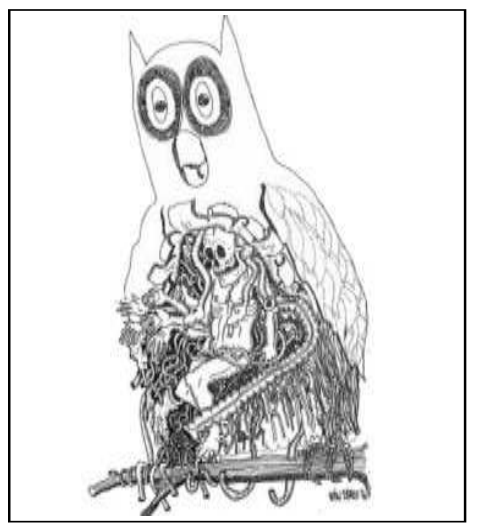

Gráfica 10 p. 7). La rebeldía contra los esquemas rígidos y geométricos llevó a nuevas formas de asumir la vida en los integrantes. Para ellos sólo tendría algún sentido su trabajo intelectual si este lograba dejar una huella entre las nuevas generaciones de lectores y creaba la llama de la contradicción en las almas de los futuros lectores y críticos de sus obras: "Sólo cuando escribimos cosas que producen rechazo, podemos comprobar que vamos bien. El día que TODOS nos acepten, ese día estaremos perdidos." 20

\section{CONCLUSIONES}

El arte crea, retarda un poco el tiempo, promueve sentido de vida y de mundo, esto es lo que permite el símbolo y la literatura. La imaginación es una forma de exorcizar la muerte, el devenir. Sin la literatura sería imposible esa constatación permanente racional de la inevitabilidad de la muerte. Los estudios del tiempo, la concepción del eterno retorno, la repetición del tiempo, son una antífrasis, una negación de la negación, una manera de repensar el devenir de la muerte. El temor a la historia decía Elia de en las culturas arcaicas lleva al ritual, al mito, porque en la repetición se niega, es el momento inevitable del tiempo, se desmitifica y domestica el tiempo.

La actitud de negación y de vacío absoluto, llevó a los nadaistas a desmitificar las tradiciones existentes. Sus escritos permitieron a los lectores repensar la historia e incidir en las futuras generaciones que apropiaron los textos y construyeron una representación de sí mismos y de la propia sociedad.

Los nadaístas crearon un lenguaje poético que se impregnó de la generalización dinámica de la imagen. El arquetipo, como una suerte de sustancia que permanece en el imaginario social, permite identificar en la revista Nadaísmo 70 esquemas recurrentes de carácter tanto ascensional como de descenso. En los escritos de los nadaístas los símbolos se actualizan en habituales referencias al sol, a la luz, a la figura del poeta como figura heroica que simboliza el deseo de un impulso ascensional.

Tanto en diferentes fuentes hermenéuticas y simbólicas como en imágenes arquetípicas y estructuras es posible encontrar la relación implícita que instauraron los nadaístas en sus producciones individuales y en su revista Nadaísmo 70: una fusión entre el mito y la literatura. La literatura al moverse entre imágenes y símbolos reivindicó

20 ARANGO, Gonzalo. (1970): "Texto de Eduardo Escobar a Regis Debray, Jaime Jaramillo Escobar" en Nadaísmo 70. No. 2, p. 15. 
el papel de la imaginación, que no es una facultad de segundo orden, pues la historia del pensamiento occidental calificó durante mucho tiempo a la imaginación como la maestra del error y la falsedad.

Para los nadaístas, América era vieja por culpa de sus descubridores. Desvelar esta historia encubierta fue su propósito (Véase gráfica 11, Rebelión en América, Nadaísmo 70, No. 5, p. 27). Para ello, se debía establecer un diálogo con la cultura universal y superar el infantilismo espiritual. "De otra manera -así lo expresaron en el Manifiesto Nadaísta - nos quedaríamos en la edad de la Rana y la Laguna, en tanto que la técnica ha fijado estrellas en el espacio cósmico". ${ }^{21}$ Los nadaístas clamaron por la libertad como un acto de compromiso y no sólo de sentimiento, ideas o pasiones. Este es su legado.

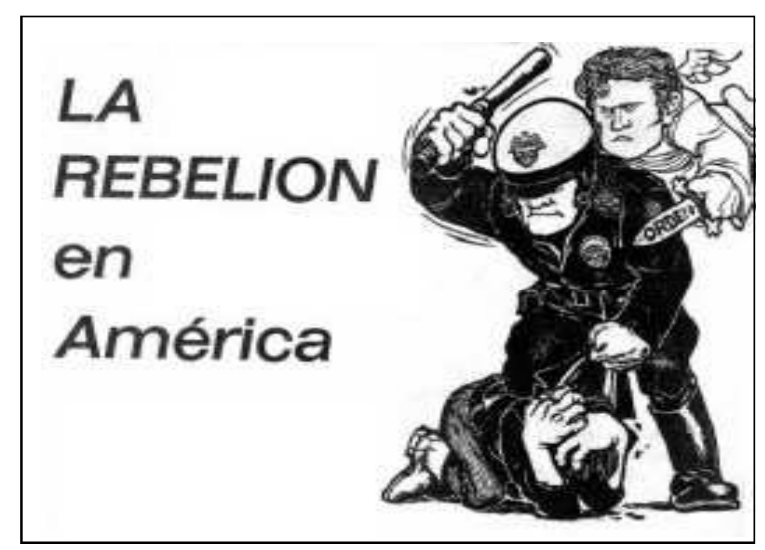

Gráfica 10

\section{FUENTES}

- Archivos de las páginas Web de El Tiempo y la revista Semana.

- Revista Nadaísmo 70

- Nadaísmo 70. (1970). Revista Americana de Vanguardia. No. 2. Bogotá

- Nadaísmo 70. (1970). Revista Americana de Vanguardia. No. 3. Bogotá.

- Nadaísmo 70. (1970). Revista Americana de Vanguardia. No. 4. Bogotá

- Nadaísmo 70. (1970). Revista Americana de Vanguardia. No. 5. Vol. I. Bogotá

- Nadaísmo 70. (1971). Revista Americana de Vanguardia. No. 6. Bogotá

- Nadaísmo 70. (1971). Revista Americana de Vanguardia. No. 8. Año II. Vol. II. Bogotá.

${ }^{21}$ PRIMER MANIFIESTO NADAÍSTA (extractos). Extraído el 30 de agosto de 2008 de: http://artespoeticas.librodenotas.com/artes/746/primer-manifiesto-nadaista-1958. 


\section{SELECCIÓN BIBLIOGRÁFICA}

ARANGO, G. (1958): Primer manifiesto nadaista. Medellín. Tipografía Amistad. (1962): "Diario de un nadaísta”, en Mito. No. 8, pp. 252-254.

(1962): “Documentos nadaístas”, en Mito. No. 8, pp. 244-251.

(1962): "Primera Bienal de las cruces”, en Mito. No. 8, pp. 261-263.

(1963): Trece poetas nadaístas. Medellín. Ediciones Triángulo.

(1963): Sexo y saxofón (cuentos). Bogotá. Ediciones Tercer Mundo.

(1964): Los ratones van al infierno y la consagración de la nada (teatro). Bogotá. Ediciones Tercer Mundo.

(1966): De la Nada al Nadaísmo. Bogotá. Ediciones Tercer Mundo.

(1966): Prosas para leer en la silla eléctrica (crónicas, ensayos,

(1968): El oso y el colibrí. Medellín. Editorial Albón.

ARBELÁEZ, J. (1993): Obra negra: negación creadora. Bogotá. Plaza y Janes.

BRUNNER, J. (1992): América Latina: cultura y modernidad. México. Grijalbo.

CAMACHO, E. (1964): "Un nadaísta en la nada”, en Boletín Cultural y Bibliográfico. No. 9, pp. 1638-1641.

CAMBIO. (2008): "50 años no es nada", en Cambio. No. 1374, septiembre 1 a 8, pp. 84-85.

CARRANZA, M. (1976): “Nota sobre el nadaísmo”, en Nueva Frontera, pp. 22-23.

CHARTIER, R. (1996): El mundo como representación. Historia cultural: entre práctica y representación. Barcelona. Gedisa. Económica.

(2000): Cultura escrita, literatura e historia. México. Fondo de Cultura

COBO BORDA, J. (1980): “El Arca de Noé del Nadaísmo”, en Gaceta. No. 3, pp. 2136.

DEAS, M. (1993): Del poder y la gramática y otros ensayos sobre historia, política y literaturas colombianas. Bogotá. Tercer Mundo.

Rhela. Vol. 12. Año 2009, pp. 62 - 78 
Una lanza por un proyecto de nación: nadaismo 70

DURAND, Gilbert (2004): Las estructuras antropológicas del imaginario. México. Fondo de Cultura Económica.

ELÍAS, N. (1994): Teoría del símbolo. Un ensayo de antropología cultural. Barcelona. Ediciones Península.

ESCOBAR, E. (1980): Correspondencia violada. Bogotá. Instituto Colombiano de Cultura.

. (1989): Gonzalo Arango. Bogotá. Editorial Nomos Ltda.

EL TIEMPO (2008): "La Furia Nadaísta”, en El Tiempo, agosto 31. Extraído el $1^{\circ}$ de septiembre de 2008 de: www.elteimpo.com.

GÓMEZ, J. (1995): “Nadaísmo y movimiento”, En Ánfora. No. 3, pp. 56-58.

HOBSBAWM, E. (1998): Historia del siglo XX. Buenos Aires. Crítica-Grijalbo. Crítica. . (1999). Gente poco corriente. Resistencia, rebelión y jazz. Barcelona.

HURTADO, C. (2002): Después del hombre. Medellín. Hombre Nuevo Editores.

JARAMILLO, D. (1984): “La poesía nadaísta", en Revista Iberoamericana. No. 50, pp. 757- 798 .

LAVERDE, M. y REGUILLO, R. (1998): Mapas Nocturnos: Diálogos con la obra de Jesús Martín-Barbero. Santafé de Bogotá. Siglo del Hombre.

LEAL, F. (1981): "La frustración política de una generación: La universidad colombiana yla formación de un movimiento estudiantil, 1958-1967”, en Desarrollo y sociedad. No. 6.

LOPERA, L. (1960): "Nada bajo el cielo raso: Gonzalo Arango o la nueva oscuridad", en Revista Universidad de Antioquia, No. 142, pp. 829-832.

MARTÍN, J. (1987): De los medios a las mediaciones: comunicación, cultura y hegemonía. México. Gustavo Gili.

MEJÍA, J. (1979). "Reflexiones en torno al nadaísmo”, En Arco. No. 226, pp. 23-31.

MONSIVÁIS, C. (2000): Aires de familia: Cultura y sociedad en América Latina. Barcelona. Anagrama.

NADAÍSMO 70 (1970-1971). Nadaísmo 70: Revista Americana de Vanguardia. Nos. 1-8.

Rhela. Vol. 12. Año 2009, pp. $62-78$ 
OSRIO, A. (1962): “Manifiesto poético”, en Mito. No. 8, pp. 257-260.

OSORIO, A. (1962): "Yo no era nadie, ahora soy nadaísta", en Mito. No. 8, pp. 255256.

OSPINA, U. (1965): “¿Hay en el nadaísmo una postura nacionalista?”, en Letras Nacionales. No.1, p. 2.

PUYANA, A. y Serrano, M. (2000). Reforma o inercia en la universidad latinoamericana: Universidad Nacional de Colombia-Universidad Autónoma de México. Colombia. TM editores.

RASCH, A. (1996): "Gonzalo Arango: 20 años después", en El Heraldo: Revista Dominical. Barranquilla. No.824, p. 3.

ROMERO, A. (1983): "El Nadaísmo y la literatura”, en Eco, No. 26, pp. 175-192.

SAMPER, D. (1966): "Nadaísmo en saldo rojo", en Boletín Cultural y Bibliográfico. No. 9, p. 6.

SÁNCHEZ, C. (1989): "El nadaísmo colombiano: Epílogo literario al Frente Nacional”, en Revista Foro. No. 8, pp. 83-94.

VALENCIA, E. (1991): “Gonzalo Arango, los nadaístas no te olvidamos". Dominical de la República, Bogotá. Octubre 27, s.p.

VOLPI, J. (2001): La imaginación y el poder: Una historia intelectual de 1.968, $1^{\mathrm{a}}$. Reimpresión. México. Era.

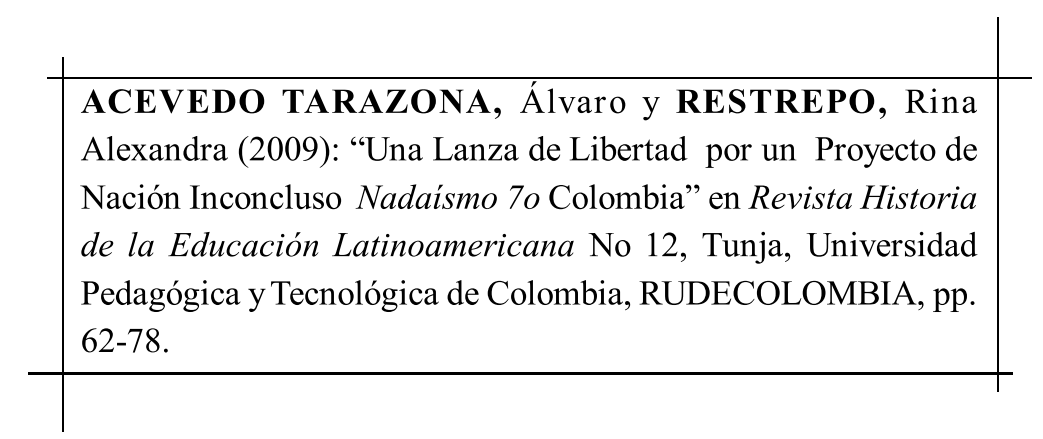

Rhela. Vol. 12. Año 2009, pp. 62 - 78 